\title{
On the occurrence of the digenean Otodistomum veliporum in the spiracle of the kitefin shark Dalatias licha
}

\author{
Emilio SPERONE* and Concetta MILAZZO \\ DiBEST, Dipartimento di Biologia, Ecologia e Scienze della Terra, Università della Calabria, \\ via P. Bucci 4B, 87027, Rende (CS), Italy
}

*Corresponding author, e-mail: emilio.sperone@unical.it

The presence of the digenean Otodistomum veliporum is reported here for the first time as a parasite in the spiracle of a Mediterranean specimen of the kitefin shark Dalatias licha.

Key words: Otodistomum veliporum, Dalatias licha, spiracle, Calabria, Mediterranean

\section{INTRODUCTION}

Otodistomum veliporum (Creplin, 1837) is a digenean trematode belonging to Family Azygiidae. It is a parasite present in body cavity, spiral valve and stomach of elasmobranchs and holocephalans. The colour of this helminth varies from opaque white to yellow and the maximum length is $80 \mathrm{~mm}$. All members of Otodistomum genus were revised and redescribed by GIBSON \& BRAY (1977). This genus has been recorded from sub-tropical, temperate, sub-Artic and subAntartic regions (THRELFALL \& CARVAJAL, 1986; ZDZITOWIECKI \& PISANO, 1996). GIBSON \& BRAY (1977) reported the species Otodistomum veliporum for the Atlantic and the Mediterranean, in particular as host in bony fish and elasmobranchs from waters off Sicily. However, little is known about this species, particularly the life cycle. Here we report for the first time the presence of this parasite in the spiracle of the kitefin shark Dalatias licha (Bonnaterre, 1788), which is a moderate sized deep-water shark unevenly distributed on continental and insular shelves and slopes in warm-temperate and tropical areas at depths of 37 to $1,800 \mathrm{~m}$ in the North and Central Atlantic, western Indian Ocean and Western and Central Pacific Ocean.

\section{MATERIAL AND METHODS}

During November 2011, a female of Dalatias licha $1100 \mathrm{~cm}$ of total length was caught in deepwater longline off the beach of Cetraro $\left(38^{\circ}\right.$ $\left.30^{\prime} \mathrm{N} ; 15^{\circ} 56^{\prime} \mathrm{E}\right)$ in the Southern Tyrrhenian Sea (Central Mediterranean Sea). Analysis of the stomach contents and internal organs has been performed. For parasitological analysis, gastrointestinal tract, as well as gills, liver, heart, and kidneys, were dissected and placed separately in Petri dishes containing 0.9\% saline solution (COMAS et al., 2014; DE DONATO et al., 2017). Ectoparasites have been searched along the whole body, including mouth and spiracle. Organs were examined separately for helminth detections under a stereomicroscope. The presence of just one Digenean elminth into the spiracle of the shark was observed. Recovered helminth was placed in vials in $70 \%$ ethanol. According to GIBSON (1996) taxonomic keys 
used for the identification of the digenean were: ventral sucker larger than oral sucker; breadth ratio between suckers in the range 1:1,5-2,1; vitellarium present into anterior $2 / 3$ of the body.

\section{RESULTS}

Only a single beak of the cephalopod Totarodes sagittatus Lamarck, 1798, which is very common in the area, and the shell of an unidentified shrimp were found in the stomach of the shark. No parasites have been found in the internal organs. Instead, the external parasitological survey confirmed the presence of one specimen of Otodistomum veliporum actively attached to the mucosa of the spiracle of the shark (Fig. 1). This parasite was easily distinguishable for the presence of two suckers close to the anterior extremity of the elminth: the ventral one $(4,5 \mathrm{~mm})$ was larger than the oral one $(2,2 \mathrm{~mm})$ with a breadth ratio of $1: 2,04$. The specimen collected was $54 \mathrm{~mm}$ body length with non-spinous cuticle and yellow body color. The digestive tract was characterized by the absence of the prepharynx, by a conspicuous pharynx and by a long and sinuous caecum, mainly extending in the posterior extremity of the elminth. The genital pore was located near the left portion of the pharynx. Vitellaria were well developed, extending from the ventral sucker to the two-thirds of the body: they were absent into the third posterior part. Two continuous ovoid testes were observed near the mid-body: ovary was located in close proximity of the anterior testis.

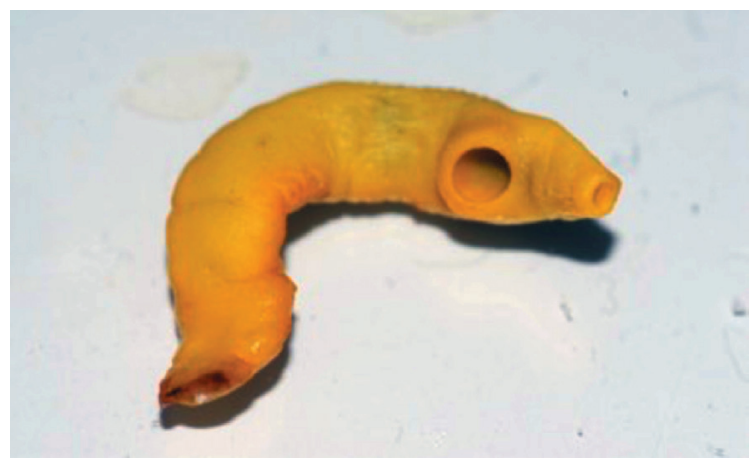

Fig. 1. Specimen of Otodistomum veliporum removed from the spiracle of Dalatias licha $($ bar $=10 \mathrm{~mm}$ )

\section{DISCUSSION}

In the Mediterranean, the range of Dalatias licha appears to be confined to the western and central basins (BAINO et al., 2001). This shark is found sporadically in the South Tyrrhenian (SPERONE et al., 2012; ZENETOS et al., 2015; KARACHLE et al., 2016) and very few information is available regarding its biology and ecology. The low reproductive rate of this species renders it susceptible to overfishing and, coupled with known population declines, has led it to be assessed as Near Threatened by the IUCN: for this reason, every information regarding distribution, biology and ecology of the species could be important.

The digenean Otodistomum veliporum is here reported for the first time as parasite of Dalatias licha in the Mediterranean Sea. This species has been reported in many elasmobranchs species (Squalus acanthias, Bathyraja richardsoni, Centroscyllium fabricii, Raja jenseni, Raja laevis, Raja ocellata, Raja radiata) from the Atlantic and the Mediterranean (GIBSON \& BRAY, 1977; GIBSON, 1996), and DAWES (1968) reported the presence of this elminth in the Pacific (Pristiophorus sp. from Australia and New Zealand). The parasite has been found in stomach, rarely oesophagus, branchial cavity and intestine. Many of the hosts examined in other papers (BRICKLE et al., 2002) showed small scars that were produced by the ventral and oral suckers of the parasite on the surface of the organs within the abdominal cavity and were most conspicuous on the liver. However, Dalatias licha examined in the present paper did not show evident scars in the abdominal organs. Scarce information is available regarding the prevalence and mean intensity of Otodistomum veliporum. SCOTT (1982) reported few numbers (1-8) of this parasite in the host. This is a common pattern for other Otodistomum species, with few exceptions like Otodistomum plunketi that showed a maximum number of specimens of 136 in Bathyraja multispinis (BRICKLE et al., 2002).

Therefore, based on previously stated, in this paper Otodistomum veliporum is reported for the first time as a parasite of the spiracle of a shark. Spiracles are breathing openings found 
in some sharks and all rays. They are a pair of openings just behind the fish's eyes that allow it to draw oxygenated water in from above, without having to bring it in through the gills. The spiracles open into the mouth and the water is passed over the gills for gas exchange and out of the body.

As Otodistomum veliporum is a parasite typical of the digestive tract, its presence in the spiracle could be interpreted as a shift occurred after the shark's death. It is reasonable to assume that it has climbed the digestive tract up to the mouth, from where it then entered the spiracle. However, we cannot entirely exclude that the spiracle could really be a site of infestation for the parasite, since it was found actively attached to the mucosa.

\section{REFERENCES}

BAINO, R., F. SERENA, S. RAGONESE, J. REY \& P. RINELLI 2001. Catch composition and abundance of elasmobranchs based on the MEDITS program. Rapports. Commission Internationale pour L'Exploration Scientifique de la Mer Mediterranee, 36: p. 234.

BRICKLE, P., J. POMPERT \& D. POULDING. 2002. The occurrence of Otodistomum plunketi Fyfe, 1953 (Digenea: Azygiidae), in Rays (Chondrichthyes: Rajidae) around Falkland Islands. Comp. Parasitol., 69 (1) : 86-89.

COMAS, M., A. RIBAS, C. MILAZZO, E. SPERONE $\&$ S. TRIPEPI. 2014. High levels of prevalence related to age and body conditions: host-parasite interactions in a water frog Pelophylax kl. hispanicus. Acta Herpetol., 9 (1): 25-31.

DAWES, B. 1968. The Trematoda. Cambridge University Press. Cambridge, 644 p.

DE DONATO, C., D. BARCA, C. MILAZZO, R. SANTORO, G. GIGLIO, S. TRIPEPI \& E. SPERONE. 2017. Is trace element concentration correlated to parasite abundance? A case study in a population of the green frog Pelophylax synkl. hispanicus from the Neto River (Calabria, southern Italy). Parasitol. Res., 116: 1745-1753.

GIBSON, D.I. 1996. Guide to the Parasites of Fishes of Canada: Trematoda. NRC Research Press. Ottawa, 373 p.

GIBSON, D.I. \& R.A. BRAY. 1977. The Azygiidae, Hirudineliidae, Ptychogonimidae, Sclerodistomidae and Syncoeliidae of fishes from the North-East Atlantic. Bull. Br. Mus., 32: 167-245

KARACHLE, P.K., A. ANGELIDIS, G. APOSTOLOPOULOS, D. AYAS, M. BALLESTEROS, C. BONN-
ICI, M.M. BRODERSEN, L. CASTRIOTA, N. CHALARI, J.M. COTTALORDA, F. CROCETTA, A. DEIDUN, Ž. ĐOĐO, A. DOGRAMMATZI, J. DULČIĆ, F. FIORENTINO, O. GÖNÜLAL, J.G. HARMELIN, G. INSACCO, D. IZQUIERDO-GÓMEZ, A. IZQUIERDO-MUÑOZ, A. JOKSIMOVIĆ, S. KAVADAS, M.A.E. MALAQUIAS, E. MADRENAS, D. MASSI, P. MICARELLI, D. MINCHIN, U. ÖNAL, P. OVALIS, D. POURSANIDIS, A. SIAPATIS, E. SPERONE, A. SPINELli, C. STAMOULI, F. TIRALONGO, S. TUNÇER, D. YAGLIOGLU, B. ZAVA \& A. ZENETOS 2016. New Mediterranean biodiversity records (March 2016). Mediterr. Mar. Sci., 17 (1): 230-252.

SCOTT J.S. 1982. Digenean parasite communities in flatfishes of the Scotian Shelf and southern Gulf of St. Lawrence. Can. J. Zool., 60 (11): 2804-2811.

SPERONE, E., G. PARISE, A. LEONE, C. MILAZZO, V. Circosta, G. SANTORO, G. PAOLILlo, P. MICARELLI \& S. TRIPEPI. 2012. Spatiotemporal patterns of distribution of large predatory sharks in Calabria (central Mediterranean, southern Italy). Acta Adriat., 53 (1): 13-24.

THRELFALL, W. \& G.L. CARVAJAL. 1986. Otodistomum cestoides (van Beneden, 1871) from two species of skates taken in Chilean waters. Mem. Inst. Oswaldo Cruz, 81: 341- 342.

ZDZITOWIECKI, K. \& E. PISANO. 1996. New records of Digenea infection elasmobranch and teleost fish off Heard Island (Kerguelen, subregion, sub-Antarctic). Arch. Fish. Mar. Res., 43: 265-272.

ZENETOS, A., E.H.K. AKEL, C. APOSTOLIDIS, M. BILECENOGLU, G. BITAR, V. BUCHET, N. CHALARI, M. CORSINI-FOKA, F. CROCETTA, 
A. DOGRAMMATZI, M. DRAKULIĆ, G. FANELLI, G. GIGLIO, A. IMSIRIDOU, K. KAPIRIS, P.K. KARACHLE, S. KAVADAS, G. KONDYLATOS, E. LEFKADITOU, L. LIPEJ, B. MAVRIČ, G. MINOS, R. MOUSSA, E. PRATO, M.A. PANCUCCI-PAPADOPOULOU, W. RENDA, N. RÍOS, S.I. RIZKALLA,
F. RUSSO, M. SERVONNAT, A. SIAPATIS, E. SPERONE, J.A. THEODOROU, F. TIRALONGO \& I. TZOVENIS 2015. New Mediterranean biodiversity records (April 2015). Medit. Mar. Sci., 16 (1): 266-284.

Received: 3 October 2017

Accepted: 28 November 2017

\title{
Pojava parazita Otodistomum veliporum u štrcalu morskog psa drkovne (Dalatias licha)
}

\author{
Emilio SPERONE* i Concetta MILAZZO \\ *e-pošta: emilio.sperone@unical.it
}

\begin{abstract}
SAŽETAK
Prvi put je zabilježena u znanstvenoj literaturi prisutnost parazita Otodistomum veliporum u štrcalu morskog psa drkovne Dalatias licha.
\end{abstract}

Ključne riječi: Otodistomum veliporum, Dalatias licha, štrcalo, Kalabrija, Sredozemlje 